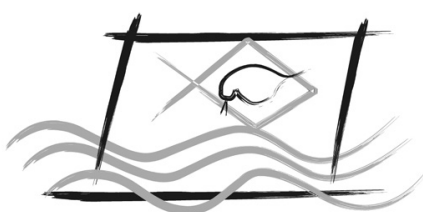

ECOTOX - BRASIL

\title{
Analysis of health status of the frog Fejervarya limnocharis (Anura: Ranidae) living in rice paddy fields of Western Ghats, using body condition factor and $\mathrm{AChE}$ content
}

\author{
G. Hegde \& S. V. Krishnamurthy \\ Department of Environmental Science, Kuvempu University, Jnana Sahyadri, Shankaraghatta 577451 , \\ Karnataka, India. Fax: +91 8282256255.
}

(Received January 17, 2014; Accept August 12, 2014)

\begin{abstract}
We evaluated the health status of common frog Fejervarya limnocharis living in rice paddy fields of Western Ghats. For this purpose, body conditions factors (CF), Hepato somatic index (HSI), Acetyl cholinesterase (AChE) activities in brain and liver tissues and morphological abnormalities of frogs living in uncontaminated and agrochemical contaminated rice paddy fields were analyzed. Pesticide residues present in the soil of contaminated rice paddy fields varied between 0.001 to $0.03 \mathrm{ppm}$, while it is undetectable in uncontaminated fields. AChE content in brain and liver tissues of frog was found to be high in uncontaminated rice paddy fields and decreased in contaminated rice paddy fields. We found a higher frequency of morphological abnormalities $(18.7 \pm 1.92 \%)$ in frogs collected from rice paddy fields with history of continuous pesticide applications, than in frogs collected from uncontaminated rice paddy fields $(3.4 \pm 1.20 \%)$. Frogs in contaminated rice paddy fields showed high HSI levels indicating stress on their liver. Presence of high HSI, morphological abnormalities, low AChE concentrations, and low body condition factor suggest a decreased health status of frogs $F$. limnocharis living in agrochemical contaminated rice paddy fields in Western Ghats.
\end{abstract}

Keywords: AChE activities, body condition factor, Fejervayra limnocharis, Hepato-somatic index, health status, morphological abnormalities.

\section{INTRODUCTION}

In the Western Ghats, agricultural lands are a complex mixture of different plantation crops, agriculture fields and commercial croplands, comprising many small pieces of land owned by different farmers, and with each piece subjected to different methods of cultivation. As a result, when farmer uses different agrochemicals, the total habitat gets contaminated with a mixture of agrochemicals (Krishnamurthy et al., 2006; Meenakumari, 2007; Gurushankara et al., 2007a; Nataraj \& Krishnamurthy, 2012). Agrochemical contaminants can affect amphibians either by destroying biodiversity at lower tropic levels followed by effect at higher tropic levels (Larson et al., 1997; Blaustein et al., 2011) or by producing negative effects at the individual level such as deviation in growth, metabolism, metamorphosis, development, behavior, survivorship, and the frequency of producing morphological abnormalities (Bishop, 1992; Carey \& Bryant, 1995; Alford \& Richards, 1999; Hayes et al., 2006; Krishnamurthy et al., 2006; Meenakumari, 2007; Gurushankara et al., 2007b; Khan \&Yasmeen, 2008; Krishnamurthy et al., 2008; Relyea, 2009; Krishnamurthy \& Smith, 2010, 2011; Smith et al., 2011). In Western Ghats, many amphibians are living and breeding in shallow waters of rice paddy fields. Generally their breeding period coincides with the application of agrochemicals, including pesticides and fertilizers (Vasudev et al., 2007; Gurushankara et al., 2007c). Earlier studies have revealed elevated frequencies of morphological abnormalities

*Corresponding author: S.V. Krishnamurthy; e-mail: svkrishnamurthy@gmail.com 
$(3.97 \%)$ in Fejervarya limnocharis from rice paddy fields (Gurushankara et al., 2007b).

Although the Western Ghats has a diverse amphibian fauna (Daniels, 2005), few toxicological studies are available (Krishnamurthy et al., 2008, Nataraj \& Krishnamurthy, 2012) focusing on effects of individual or combinations of agrochemicals on larvae of amphibians. However, effect of agrochemicals on amphibian health status at field conditions are largely unknown. Hence for the first time, we evaluated the health status of this frog living in the rice paddy fields using body condition factor (CF), incidences of morphological abnormalities, Hepato-somatic index (HSI) and Acetylcholine esterase (AChE) activity in brain and liver tissues as indicators of stress. In this study, we checked the hypothesis that the agrochemicals produce negative effects on health status of frogs Fejarvarya limnocharis (Anura: Ranidae) living in rice paddy fields of Western Ghats.

\section{MATERIALS AND METHODS}

\section{Study Sites}

The study was conducted on samples of frogs collected from nine sites (site 1 to 9) (Loc: $13^{\circ} 25^{\prime} 46^{\prime \prime}-14^{\circ} 02^{`} 48^{\prime \prime} \mathrm{N}$ and $75^{\circ} 02{ }^{`} 46^{\prime \prime}-75^{\circ} 42^{`} 26^{\prime \prime} \mathrm{E}$ ) located at different places in Central Western Ghats. Each site has an area of approximately 3.65 ha. Table 1 details the site description. Sites 1 to 3 are uncontaminated and considered reference sites. Sites 4 to 6 are located near water sources (viz., ponds, river and reservoir channel) at low altitude. Sites 7 to 9 are located at high altitudes where pesticides are applied regularly for every crop. In site $1-3$, the rice paddy cultivation is being made using organic manures, while in site 4-6, farmers do not use large amount of agrochemicals directly, but the habitat water receives agrochemicals residues from run-off of adjoining high altitude crop fields. In site 7-9, farmers use different pesticides viz., Nuvacran (250 mL/acre/crop), Monocrotophos (250 mL/acre/ crop), Methyl Parathion (300 mL/acre/crop), Dicrotophos (200 mL/acre/crop), and three major chemical fertilizers -Di ammonium Phosphates (100 kg/acre/crop), Nitro-phosphate and Potash (75 kg/acre/crop) and Urea (150 kg/acre/crop) regularly. We interviewed farmers using questionnaire at each site to gather information on managerial practices, and the amount of pesticides, fertilizers and other agrochemicals being used.

\section{Frog Sampling}

Frogs were sampled from all sites during the monsoon (June-September) to early post monsoon (October) seasons in 2012 at a time following the application of agrochemicals (pesticide and synthetic fertilizers) to rice paddy crops. Surveys were made at each site at an interval of 40 days for 5 months. During sampling, $9.4 \pm 1.25$ man hrs were spent in each 3.65 ha. area. Surveys were generally done during early morning and late evening hours. Frogs were collected by searching all microhabitats of the paddy fields. When frogs were found; they were handpicked and transferred to an inert polythene container. Once the collections of the frogs were over, they were transferred to a larger container and were counted. Snout-Vent-Length (SVL) was measured to nearest $0.01 \mathrm{~mm}$ using a digital caliper (make: Tresna), and body mass (BM; to nearest $0.1 \mathrm{~g}$ ) was recorded using a portable balance (make: Dura Scale, D2). Later each frog was visually examined for the presence of morphological abnormalities. Any morphological deviations, like small eye, short finger/toe in limbs, missing toe, rotation at limb joint, bone-bridge and web in skin etc., compared with normal frog are considered as an abnormality. The type of abnormality was identified following Meteyer (2000) and their incidences were recorded. From every survey, a subsample of frogs (30\%) was randomly chosen and used for laboratory biochemical analysis. The remaining $(70 \%)$ frogs were released back to their habitat. Total of 292, 295 and 261 adult frogs were collected from sites 1-3, 4-6 and 7-9, respectively. Out of these, 88 (60 males and 28 females), 96 (70 males and 26 females) and 86 (55 males and 31 females) frogs were used for detailed laboratory analysis respectively. As $F$. limnocharis is a common inhabitant, generally breeds and lives in shallow water and wet soil of rice paddy fields, applications of agrochemicals on paddy crop have posed a threat to them (Gurushankara et al., 2007b). Since we have conducted survey over a vast area in each site, our survey has provided a good number of frogs in every collection for the detailed analysis.

Table 1 - Description of the study sites.

\begin{tabular}{|c|c|c|c|}
\hline Sites No. & Nature of the site & $\begin{array}{l}\text { Proximity to Permanent Water } \\
\text { body (distance in m) }\end{array}$ & Agro-chemicals source \\
\hline $1-3$ & $\begin{array}{l}\text { Control (reference) sites } \\
\text { (alt: 607-646 m.asl) }\end{array}$ & $50-400$ & NIL (organic cultivation) \\
\hline $4-6$ & $\begin{array}{l}\text { Indirectly contaminated } \\
\text { sites } \\
\text { (alt: } 600-645 \text { m.asl) }\end{array}$ & $50-400$ & $\begin{array}{c}\text { Low lying cropland which receives } \\
\text { the water from other cropland } \\
\text { where agro-chemicals are being } \\
\text { used. }\end{array}$ \\
\hline $7-9$ & $\begin{array}{l}\text { Contaminated sites } \\
\text { (alt: } 625-647 \text { m.asl) }\end{array}$ & $25-1000$ & $\begin{array}{l}\text { Five different varieties of synthetic } \\
\text { pesticides and three varieties of } \\
\text { synthetic fertilizers are regularly } \\
\text { used for every rice paddy crop. }\end{array}$ \\
\hline
\end{tabular}




\section{Soil sampling and Pesticide residues in soil}

As water in all sites was not constantly available, we collected surface soil from each sampling site for pesticide residue analysis. Five soil samples are collected randomly in each sampling site from a surface area to $10-20 \mathrm{~cm}$ depth and were brought to the laboratory in sterile polythene bags. Later, soil samples were air dried at room temperature for about 24-48 hours. Then dried samples were powdered and sieved (pore size: $2 \mathrm{~mm}$ ). Later, these samples were sent to the Indian Institute of Horticulture Research, Bangalore for pesticide analysis using GC-MS. Total pesticide residues varied between 0.001 to $0.03 \mathrm{ppm}$ in sampling sites 4 to 9 , while pesticide residue was undetectable in sites 1-3.

\section{Estimation of Body condition factor (CF)}

We estimated the body condition factor (CF) as described by Brodeur et al., (2011). To derive the CF regression line equation of BM on SVL, data on frogs collected from reference sites was used. This BM v/s SVL equation is regarded as reference and represents a healthy condition. Then, using the same equation, the theoretical body mass for frogs collected from contaminated sites (site 4-6 and 7-9) were calculated, by substituting respective SVL to the equation. Then, calculated BM was subtracted from the observed BM of respective frogs to derive "residual" values. These residual values were considered for all comparison. In this method, the CF with positive residuals is represents good health condition whereas those with negative residuals are regarded as having a poor health condition (Schulte-Hostedde et al., 2005).

\section{Determination of Hepato-Somatic Index (HSI) and AChE Enzyme activity}

Each frog in the subsample was weighed in the laboratory using an electronic balance (make: Ohaus, model: 214C) to a precision of $0.1 \mathrm{mg}$. Then frogs were anesthetized using benzocaine hydrochloride, later euthanized by pithing. Afterwards, each frog was dissected to remove brain and liver tissues. Each removed organ was then weighed. HSI (\%) was calculated by dividing liver mass (g) by BM (g) and multiplied by 100 (Jelodar \& Fazli, 2012).

Acetylcholine Esterase (AChE) activity in brain and liver tissues were estimated following the method of Ellman et al., (1961). Immediately after dissection, tissues were quickly excised into cold ringer solution. Tissues were homogenized with SET buffer (Sucrose $250 \mathrm{mM}$, EDTA $1 \mathrm{mM}$, Tris- $\mathrm{HCl}$ $50 \mathrm{mM}, \mathrm{pH}$ 7.4). Homogenates were centrifuged at 10,000 rpm for 10 minutes. The resultant supernatants were frozen at $18^{\circ} \mathrm{C}$ until enzyme activity was evaluated. The reaction media used were $2.9 \mathrm{~mL}$ potassium phosphate buffer $0.1 \mathrm{M}$ $\mathrm{pH} 8,50 \mu \mathrm{L}$ of DTNB $10 \mathrm{mM}$ (dithio bis nitro benzoic acid) and $20 \mu \mathrm{L}$ of acetyl thio choline iodide of $78 \mathrm{mM}$ and the reactions performed at $37^{\circ} \mathrm{C}$ were initiated by adding small aliquots of the substrate (acetyl thio choline iodide) to yield a final volume of $3 \mathrm{~mL}$. Absorbance was recorded at $412 \mathrm{~nm}$ continuously for 5 min by using a UV spectrophotometer (Make: Shimadzu -1800).

\section{Data Analysis}

All data were subjected to Bartlett statistics to check the normality. As it was found that data of SVL and BM have identical standard deviations, we transformed these data into logarithmic values. We used ANOVA to test the occurrence of significant differences between sites. To compare CF between sites, we used ANCOVA with SVL and BM as covariates. $\chi^{2}$ analysis was used to compare the frequencies of abnormalities between sites. SPSS (ver.21.0) is used for all statistical analysis.

\section{RESULTS}

\section{Length-Mass Relationship and Condition Factor}

SVL did not vary significantly among sites (site 1-3: $27.69 \pm 2.081 \mathrm{~mm}$, sites $4-6: 27.19 \pm 2.608 \mathrm{~mm}$ and site $7-9 ; 27.60 \pm 2.707 \mathrm{~mm})$ and differences are statistically insignificant $\left(F_{2,267}=0.52, p=0.594\right)$. The average $\mathrm{BM}$ of the frogs in reference sites (1-3) was $2.14 \pm 0.641 \mathrm{~g}$, whereas those of contaminated sites 4-6 and 7-9 were $2.05 \pm 0.739$ $\mathrm{g}$ and $2.13 \pm 0.745 \mathrm{~g}$ respectively. Similar to SVL, the BM of the frogs from different sites did not vary significantly $\left(F_{2,267}=0.50, p=0.607\right)$. Figure 1 represents the log length$\log$ mass relationship of frogs in reference sites (site 1-3), and contaminated sites (site 4-6) and (site 7-9). In all three cases, as the log SVL increases, corresponding log BM also increased (site 1-3: $r=0.89, p=0.0001$, site 4-6: $r=0.92$, $p=0.0001$, site 7-9: $r=0.93, p=0.0001)$. However, the regression equation indicates differences between reference sites and contaminated sites. The CF of frogs living in site 4-6 are different from those living in site 7-9 (Figure 2). A total of $53 \%$ of frogs in site 4-6 showed negative CF value (mean CF: $-0.12 \pm 0.011$ ), while it was $45 \%$ (mean CF: $-0.05 \pm 0.031)$ in site 7-9. CF showed a significant negative correlation with Log SVL in site 4-6 $(r=-0.45, p=0.0001)$ indicating the derived body mass for frogs of this site decreased with the increase of SVL, however, it is of very low magnitude as indicated by regression line $\left(\mathrm{y}_{\mathrm{c}}=-2.10 * \operatorname{logSVL}\right.$ $+3.01)$. Such relationship was marginal in site 7-9 $(r=0.21$, $p=0.056$ and $\left.\mathrm{y}_{\mathrm{c}}=0.33 * \operatorname{logSVL}-0.47\right)$. The CF showed significant difference among reference and contaminated sites (ANCOVA; $F_{2,265}=3.09, p=0.047$, Table 2).

\section{Hepato-Somatic Index (HSI)}

The average HSI was found to be 1.84, 1.93 and $1.91 \%$ respectively in reference and contaminated sites (4-6 and 7-9). Compared to reference, site 4-6 showed an increase of 5.07\% HSI, while it was $4.16 \%$ in sites 7-9. However these differences are not statistically significant $\left(F_{2,267}=1.16, p=0.314\right)$. 

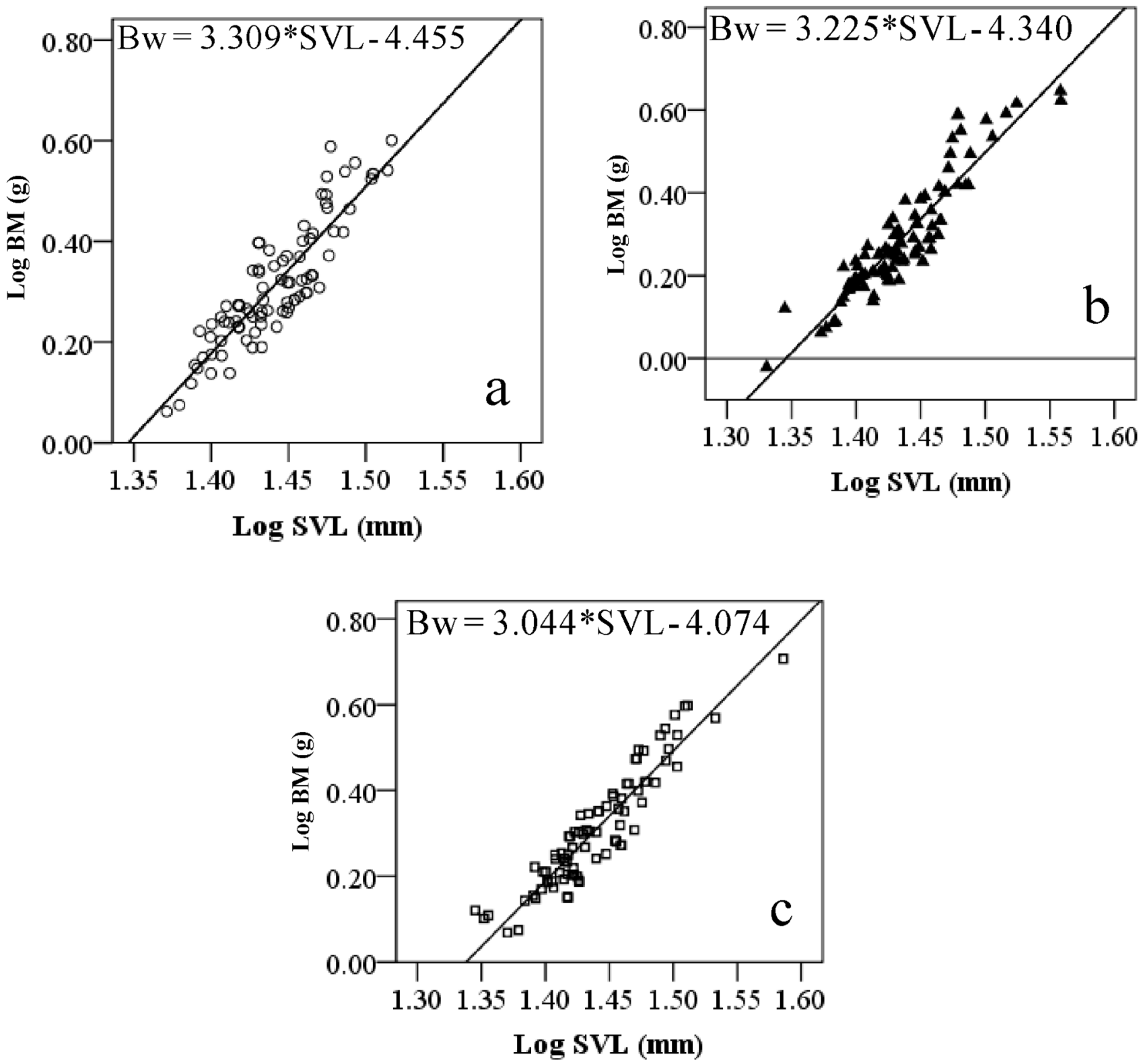

Figure 1 - Distribution of body mass $(\mathrm{g})$ as a function of SVL $(\mathrm{mm})$ for adult frogs collected in reference sites 1-3 (a), agrochemical contaminated sites 4-6 (b) and site 7-9 (c) in the study area.

\section{AChE Activity in Brain and Liver}

$\mathrm{AChE}$ activity in brain tissues of frogs collected from reference sites were highest $(0.00168 \pm 0.000083 \mu \mathrm{g} / \mathrm{mg}$ proteins) followed by frogs collected from sites 4-6 (0.00149 $\pm 0.000105 \mu \mathrm{g} / \mathrm{mg}$ proteins $)$ and then sites 7-9 ( $0.00134 \pm$ $0.000132 \mu \mathrm{g} / \mathrm{mg}$ proteins). Compared to reference sites, reduction in AChE was at the order of $10.7 \%$ and $23.1 \%$ in sites 4-6 and 7-9 respectively. The differences in AChE activity in all sites are significant $\left(F_{2,267}=186.33, p<0.0001\right)$.

The AChE activity in liver tissue of frog was highest at the reference sites $(0.00075 \pm 0.000052 \mu \mathrm{g} / \mathrm{mg}$ proteins), followed by sites $4-7(0.00054 \pm 0.000073 \mu \mathrm{g} / \mathrm{mg}$ proteins $)$ and then $7-9(0.00042 \pm 0.000049 \mu \mathrm{g} / \mathrm{mg}$ proteins $)$. The differences in AChE of liver between sites are significant $\left(F_{2,267}=690.48, p\right.$
$<0.0001)$. Compared to reference sites these differences are at the order of $39.91 \%$ (site $4-6$ ) and $78.57 \%$ (site 7-9).

\section{Morphological Abnormality}

We observed six major morphological abnormalities as presented in table 3. Maximum (total) incidence of abnormality $(18.7 \pm 1.92 \%)$ was recorded in site $7-9$, followed by $10.4 \pm$ $1.48 \%$ in site $4-6$ and least $(3.4 \pm 1.20 \%)$ in the reference site (1-3). The differences in incidences of morphological abnormality are significant at $90 \%$ level $\left(\chi^{2}=14.2, p=0.069\right.$, $d f=2$ ). All six types of major abnormalities were observed in sites 7-9, followed by four types site in 4-6, and only two types in reference sites. Brachydactyly (short toes with missing phalanges) and tibio-fibular bone bridge are common in all 


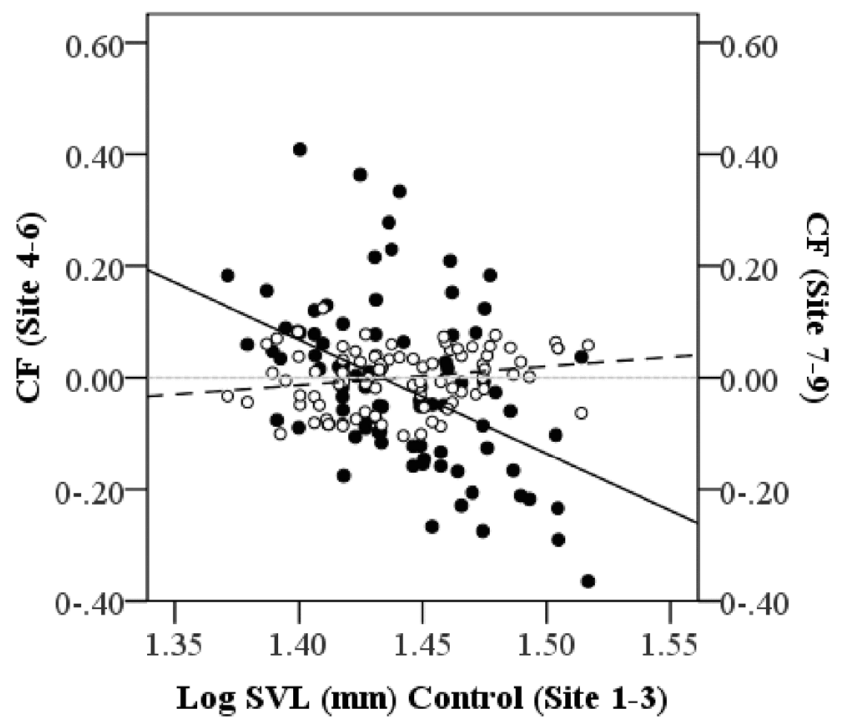

Figure 2 - Condition factor (CF) for BM of frogs collected from site 4-6 and 7-9 plotted against SVL of reference sites (1-3) as an indicator of differences between reference sites and contaminated sites. Closed circle and dark line represents CF and regression line for sites 4-6, while open circle and dotted line represents sites 7-9.

sites, however, their incidences are low in sites 1-3. Percent incidences of occurrence of bone bridge increase from sites $1-3$ to $7-9$ and maximum of $5.8 \pm 0.64 \%$ was recorded in the highly contaminated sites. Brachydactyly was high in sites 4-6 compared to sites 7-9 and 1-3. Skin web and limb rotation were observed only in sites 7-9. We observed both unilateral and bilateral skin web and tibio-fibular rotation in limb in sites 7-9.

\section{DISCUSSION}

Body condition has been used as an indicator of health of frogs (Meteyer, 1997; Schulte-Hostedde et al., 2005; Brodeur et al., 2011; Thammachoti et al., 2012). Frogs in contaminated ecosystem generally show low CF (Thammachoti et al., 2012). Hayes et al., (2006) highlighted the importance of body size, as smaller frogs are liable to predation. However, in the present study neither SVL nor BM showed differences among different sites, despite of the high pesticide contamination in sites 4-9. Brodeur et al. (2011) observed a reduced body condition in frogs living in soy cultivated lands with pesticide application and further suggested that the lower condition factor could be an indicator of reduced fitness due to reduced reproductive output and survival. Therefore, deviation of CF recorded in pesticide contaminated rice paddy fields could not be ruled

Table 2 - Result of statistical analysis (ANCOVA) showing the clear differences in $\mathrm{CF}$ recorded between reference and contaminated sites. (Note: $\mathrm{a}=$ computed using alpha at 0.05 ).

\begin{tabular}{lccccccc}
\hline & $\begin{array}{c}\text { Sum of } \\
\text { Squares }\end{array}$ & df & $\begin{array}{c}\text { Mean } \\
\text { Square }\end{array}$ & F & Sig. & $\begin{array}{c}\text { Noncent. } \\
\text { Parameter }\end{array}$ & $\begin{array}{c}\text { Observed } \\
\text { Power }^{\mathrm{a}}\end{array}$ \\
\hline $\begin{array}{l}\text { Body } \\
\text { Condition }\end{array}$ & $2.218 \mathrm{E}-005$ & 2 & $1.109 \mathrm{E}-005$ & 3.09 & 0.047 & 6.176 & 0.592 \\
$\begin{array}{l}\text { Factor } \\
\text { Error }\end{array}$ & 0.001 & 265 & $3.591 \mathrm{E}-006$ & & & \\
\hline
\end{tabular}

out as a potential indicator of agrochemicals influence on frogs. Changes in HSI generally indicate an effect of chemical exposure on liver function (Peakall, 1976; Anderson et al., 1988; Gabriel et al., 2009; Paunescu \& Ponepal, 2011). In the present study, frog samples from pesticide contaminated sites showed relatively high level of HSI (\%) indicating the stress on liver.

Amphibians are highly vulnerable to pesticides that are cholinesterase inhibitors. Many studies have indicated that pesticide reduce cholinesterase activities in amphibians (Widder \& Bidwell, 2006; Khan et al., 2007; Tongo et al., 2012). Bradford et al., (2011) found low frequency ( $>30 \%$ ) of $\mathrm{ChE}$ inhibition in Rana population exposed to chlorpyrifos and considered that this was due to exposure pesticide on tadpoles. A depression in $50 \% \mathrm{ChE}$ activity from the reference line is generally considered as a forensic threshold for pesticide caused inhibition in vertebrates (Hill \& Flemming, 1982). Therefore, as a tool or biomarker, inhibition of the enzyme acetylcholinesterase (AChE) by pesticides is being applied throughout the animal kingdom (Rojas-Garcia et al., 2011). In the Western Ghats, organochlorine (Lindane), carbamate (Marshal), organophosphate (Tricel) insecticides, and fungicides (Bordaux mixture) are used regularly in coffee plantations on the hill slopes. Similarly, in agricultural fields organochlorine and organophosphate insecticides are used. In particular, organophosphate pesticides are used intensively in rice paddy cultivation (Vasudev et al., 2007; Nataraj \& Krishnamurthy, 2012). Organochlorine and organophosphate pesticides are known to produce AChE-inhibition and are also believed to cause malformations in frogs (Fort \& Paul, 2002; Fort et al., 2004a; Fort et al., 2004b; Krishnamurthy \& Smith, 2010).

In earlier studies, $F$. limnochairs collected from the agrochemical contaminated area have showed tumors with disfigured hind limb bones, short-toe, missing digit, and incomplete limb in (Patel et al., 2008). Morphological abnormalities in tadpoles and adults of other species were also observed in field studies (Vasudev et al., 2007; Gurushankara et al., 2007b). Further, tadpoles of $F$. limnochairs have exhibited deviation in normal growth and mortality when they were treated with malathion (Gurushankara et al., 2007a, c).

In this study, we found higher incidences of morphological abnormalities in the contaminated sites (site 4-9). Such abnormalities can be caused by several factors including radiation, hyperthermia, low oxygen, high $\mathrm{CO}_{2}$, poor nutrition,

Table 3 - Incidences of morphological abnormalities ( $\% \pm \mathrm{SE})$ recorded in frogs of F. limnocharis at different sampling sites.

\begin{tabular}{lccc}
\hline \multirow{2}{*}{ Abnormality } & \multicolumn{3}{c}{ Sites } \\
\cline { 2 - 4 } & $1-3$ & $4-6$ & $7-9$ \\
\hline Microphthalmia & - & $3.1 \pm 0.08$ & $5.8 \pm 0.86$ \\
Brachydactyly & $2.3 \pm 0.10$ & $4.2 \pm 0.83$ & $3.5 \pm 0.25$ \\
Bone Bridge- tibio fibula & $1.1 \pm 0.02$ & $2.1 \pm 0.21$ & $5.8 \pm 0.64$ \\
Ectodactyly & - & $1.0 \pm 0.04$ & $1.2 \pm 0.03$ \\
Skin Web & - & - & $1.2 \pm 0.04$ \\
Ectrodactyly - Limb & - & - & $1.2 \pm 0.10$ \\
Rotation-Tibiafibula & & & \\
\hline
\end{tabular}


and endogenous or exogenous chemicals (Burkhart et al., 2000). At present, there is little information on the influence of endogenous and exogenous factors associated with the selected habitats. However, we considered pesticide residues in soil as an important factor to classify the sampling sites into three categories (viz., uncontaminated reference site and two contaminated sites) and used HSI, AChE activity and body condition and malformation to indicate the health status of frogs in rice paddy agroecosystem.

Higher morphological abnormalities in contaminated sites depicted partly by CF and directly by HSI, and AChE activities of brain and liver tissues. The CF mildly correlates with the presence of morphological abnormalities, in spite of considerable concentrations of pesticide contaminations. This could be indirectly attributed to the regional factors such as frequent torrential rainfall in monsoon, steep physiographic relief of the area, etc. which could have reduced the impact by diluting agrochemical concentrations. Further, during the monsoon, frogs could have locally moved in to contaminated sites from adjoining native-uncontaminated habitats and vis-a-vis moved out of contaminated sites. This might have reduced the number of frogs in the sample which showed the negative CF.

Some studies have shown that amphibian populations living in agroecosystems have a higher prevalence of abnormalities (Ouellet et al., 1997, Gurushankara et al., 2007b). On the other hand, similar studies are not consistent with these results (Johnson et al., 2003; Piha et al., 2006), and in some cases, it was reported higher prevalence of abnormalities in areas without agricultural alterations (Agostini et al., 2013). However, it is often common possible association between increased incidences of malformation with specific sites or conditions (Burkhart et al., 2000). It has been found that many factors, such as genetic or environmental factor like exogenous chemicals can acts as a teratogens and can induce errors in development which results in malformation (Palmer et al., 1998; McCoy et al., 2008). Among exogenous chemicals, agrochemicals play a major role negatively contributing to the health of frogs living in agroecosystem (Mann et al., 2009). Many frogs and toads exposed to pesticides exhibit morphological abnormalities and do not survive to adulthood (Kegley et al., 1997; Ali et al., 2011). However, possible causes of amphibian morphological abnormalities are said to be expansive including parasites, UV radiation, other chemical and heavy metal contaminations etc., (Burkhart et al., 2000; Reeves et al., 2010). But in the present study, we considered a few indicators to represent health status, therefore, there is scope for an in depth study considering all other possible factors. However, frogs living in cultivated crop lands shows decreased health status. Health status is indicated by means of biomarkers like HSI, AChE and to a certain extent body condition factor and the morphological abnormalities of frogs F. limnocharis in rice paddy fields.

\section{CONCLUSION}

The present study compared the CF, HSI, AChE activities and occurrences of morphological abnormalities in frogs living in rice paddy fields under different managerial practices and pesticide applications. We collected frogs for this study just after the application of synthetic fertilizers and pesticides in sites 4-9. Further, in these sites the agrochemicals are being intensively used for every crop, as confirmed through questionnaires. Continuous application of agrochemicals, particularly pesticides, has caused residues to accumulate in the soil. Therefore, frogs in contaminated sites were presumed to be exposed continuously by both current application and residues present in their habitat. The changes in CF, HSI, $\mathrm{AChE}$ concentrations and occurrence of morphological abnormalities as observed in this study would be the result of continuous and indirect exposure to agro-chemical residues present in soil and water and also recent exposures to various chemicals by local agriculture practices.

\section{ACKNOWLEDGEMENTS}

Ganapati Hegde thanks Department of Science and Technology, Govt. of India, for awarding INSPIRE Fellowship. SVK is thankful to UGC for awarding research project F.No.34-65/2008 (SR) dtd.30 ${ }^{\text {th }}$ Dec. 2008. Mr. Mahesh has helped in field work conducted during this study.

\section{REFERENCES}

AGOSTINI, M.G., KACOLIRIS, F., DEMETRIO, P., NATALE, G.S., BONETTO, C. \& RONCO, AE. 2013. Abnormalities in amphibian populations inhabiting agroecosystems from Northeastern of Buenos Aires province, Argentina. Dis. Aquat. Organ. 104:163-171. http://dx.doi.org/10.3354/dao02592.

ALFORD, R.A. \& RICHARDS, S.J. 1999. Global amphibian declines: A problem in applied ecology. Annu. Rev. Ecol. Syst. 30:133-165. http://dx.doi.org/10.1146/annurev.ecolsys.30.1.133

ALI, S.F.M., SHIEH, B.H.H., ALEHAIDEB, Z., KHAN, M.Z., LOUIE, A., FAGEH, N. \& LAW, F.C.P. 2011. A review on the effects of some selected pyrethroids and related agrochemicals on aquatic vertebrate biodiversity. Can. J. Pure. Appl. Sci. 5:1455--1464.

ANDERSON, T., FORLIN, L., HARDIG, J. \& LARSSON, A. 1988. Physiological disturbances in fish living in coastal water polluted with bleached kraft mill effluents. Can. J. Fish. Aquat. Sci. 45:1525-1536. http://dx.doi.org/10.1139/f88-181

BISHOP, C.A. 1992. The effects of pesticides on amphibians and the implications for determining causes of declines in amphibian populations. In Declines in Canadian amphibian populations: designing a national monitoring strategy. Canadian Wildlife Service, Occas. Pap No. 76:67-70.

BLAUSTEIN, A.R., BARBARA, A.H., RELYEA, R.A., JOHNSON, P.T.J., BUCK, J.C., GERVASI, S.S. \& KATS, L.B. 2011. The complexity of amphibian population declines: understanding the role of cofactors in driving amphibian losses. Ann. N. Y. Acad. Sci. 1223:108-119. http://dx.doi.org/10.1111/j.17496632.2010.05909.x

BRADFORD, D.F., KNAPP, R.A., SPARLING, D.W., NASH, M.S., STANLEY, K.A., TALLENT-HALSELL, N.G., MCCONNELL, L.L. \& SIMONICH, S.M. 2011. Pesticide distributions and population declines of California, USA, alpine frogs, Rana muscosa and Rana sierrae. Environ. Toxicol. Chem. 30:682-691. http://dx.doi.org/10.1002/etc.425 
BRODEUR, J.C., SUAREZ, R.P., NATALE, G.S., RONCO, A.E. \& ZACCAGNINI, M.E. 2011. Reduced body condition and enzymatic alterations in frogs inhabiting intensive crop production areas. Ecotoxicol. Environ. Saf. 74:1370-1380. http://dx.doi.org/10.1016/j.ecoenv.2011.04.024.

BURKHART, J.G., ANKLEY, G., BELL, H., CARPENTER, H., FORT, D., GARDINER, D., GARDNER, H., HALE, R., HELGEN, J.C., JEPSON, P., JOHNSON, D., LANNOO, M., LEE, D., LARY, J., LEVEY, R., MAGNER, J., METEYER, C., SHELBY, M.D.,\& LUCIER, G. 2000. Strategies for assessing the implications of malformed frogs for environmental health. Environ. Health. Perspect. 108:83-90.

CAREY, C. \& BRYANT, C.J. 1995. Possible interrelationships among environmental toxicants, amphibian development, and decline of amphibian populations. Environ. Health. Perspect. 103:13-17.

DANIELS, R.J.R. 2005. Amphibians of peninsular India. Indian. Acad. Sci. 1-258.

ELLMAN, L., COURTEY, K.D., ANDREAS, V.Jr. \& FEATHERSTONE, R.M. 1961. A new rapid colorimetric determination of cholinesterase activity. Biochem. Pharmacol. 7:88-95. http://dx.doi.org/10.1016/0006-2952(61)90145-9

FORT, D.J. \& PAUL, R.R. 2002. Enhancing the predictive validity of frog embryo teratogenesis assay - Xenopus (FETAX). J. Appl .Toxicol. 22:185-191. http://dx.doi.org/10.1002/jat.848

FORT, D.J., GUINEY, P.D., WEEKS, J.A., THOMAS, J.H., ROGERS, R.L., NOLL, A.M \& SPAULDING, C.D. 2004a. Effect of methoxychlor on various life stages of Xenopus laevis. Toxicol. Sci. 8:454-466. http://dx.doi.org/10.1093/toxsci/kfh243

FORT, D.J., ROGERS, R.L., THOMAS, J.H., BUZZARD, B.O., NOLL, A,M. \& SPAULDING, C.D. 2004b. Comparative sensitivity of Xenopus tropicalis and Xenopus laevis as test species for the FETAX model. J. Appl. Toxicol. 24:443-457. http://dx.doi.org/10.1002/jat.997

GABRIEL, U.U., OBOMANU, F.G. \& EDORI, O.S. 2009. Haematology, plasma enzymes and organ indices of Clarias gariepinus after intramuscular injection with aqueous leaves extracts of Lepidagathis alopecuroides. Afr. J. Biochem. Res. 3:312-316.

GURUSHANKARA, H.P., MEENAKUMARI, D., KRISHNAMURTHY, S.V. \& VASUDEV, V. 2007a. Impact of malathion stress on lipid metabolism in limnonectus limnocharis. Pestic. Biochem. Physiol. 88:50-56. http://dx.doi.org/10.1016/j. pestbp.2006.08.012

GURUSHANKARA, H.P., KRISHNAMURTHY, S.V. \& VASUDEV, V. 2007b. Morphological abnormalities in natural populations of common frogs inhabiting agroecosystem of the central Western Ghats. Appl. Herpetol. 4:39-45. http://dx.doi. org/10.1163/157075407779766651

GURUSHANKARA, H.P., KRISHNAMURTHY, S.V. \& VASUDEV, V. 2007c. Effect of malathion on survival, growth and food consumption of Indian cricket frog (Limnonectus limnocharis) tadpoles. Arch. Environ. Contam. Toxicol. 52:251256. http://dx.doi.org/10.1007/s00244-006-0015-5

HAYES, T.B., CASE, P., CHUI, S., CHUNG, D., HAEFFELE, C., HASTON, K., LEE, M., MAI, V.P., MARJUOA, Y., PARKER, J. \& TSUI, M. 2006. Pesticide mixtures, endocrine disruption and amphibian declines: Are we underestimating the impact? Environ. Health. Perspect. 114: 40-50. http://dx.doi.org/10.1289/ ehp.8051

HILL, E.F. \& FLEMING, W.J. 1982. Anticholinesterase poisoning of birds: Field monitoring and diagnosis of acute poisoning. Environ. Toxicol. Chem. 1:27-38. http://dx.doi.org/10.1002/ etc. 5620010105
JELODAR, H.T. \& FAZLI, H. 2012. Monthly changes in condition, hepatosomatic index and bioavailability in frogs ( Rana ridibunda). Res. J. Biol. 2:9-14.

JOHNSON, P.T.J., LUNDE, K.B., ZELMER, D.A. \& WERNER, J.K. 2003. Limb deformities as an emerging parasitic disease in amphibians: evidence from museum specimens and resurvey data. Conserv. Biol. 17: 1724-1737. http://dx.doi.org/10.1111/ j.1523-1739.2003.00217.x

KEGLEY, S., NEUMEISTER, L. \& MARTIN, T. 1997. Disrupting the balance: Ecological impacts of pesticides in California. Pesticide Action Network, USA. p 99.

KHAN, M.Z., RAIS, M. \& YASMEEN, G. 2007. Inhibitory effects on cholinesterase activity produced by the two different pesticides on brain, liver and kidney of Euphlyctis cyanophlyctis. J. Exp. Zool. India. 10:89-93.

KHAN, M.Z. \& YASMEEN, G. 2008. Effects of sandaphose and beta-cypermethrin on cholinesterase and alkaline phosphatase activity in liver, kidney and brain of Euphlyctis cyanophlyctis. CJPAS. 2:511-519.

KRISHNAMURTHY, S.V., MEENAKUMARI, D., GURUSHANKARA, H.P. \& GRIFFITHS, R.A. 2006. Effects of nitrate on feeding and resting of tadpoles of Nyctibatrachus major (Anura: Ranidae). Australasian J. Ecotoxicol. 12:123-127.

KRISHNAMURTHY, S.V., MEENAKUMARI, D., GURUSHANKARA, H.P. \& VASUDEV, V. 2008. Nitrateinduced morphological anomalies in the tadpoles of Nyctibatrachus major and Fejervarya limnocharis (Anura: Ranidae). Turk. J. Zool. 32: 239-244.

KRISHNAMURTHY, S.V. \& SMITH, G.R. 2010. Growth, abnormalities, and mortality of tadpoles of American toad exposed to combinations of malathion and nitrate. Environ. Toxicol. Chem. 29: 2777-82. http://dx.doi.org/10.1002/etc.331

KRISHNAMURTHY, S.V.\& SMITH, G.R. 2011. Combined effects of malathion and nitrate on early growth, abnormalities, and mortality of wood frog (Rana sylvatica) tadpoles. Ecotoxicology, 20:1361-7. http://dx.doi.org/10.1007/s10646-011-0692-3.

LARSON, S.J., CAPEL, P.D. \& MAJEWSKI, M,S. 1997. Pesticides in surface waters: distribution, trends, and governing factors. Ann. Arbor. Inc. USA. http://dx.doi.org/10.1002/ep.670180107

MANN, R.M., HYNE, R.V., CHOUNG, C.B. \& WILSON, S.P. 2009. Amphibians and agricultural chemicals: review of the risks in a complex environment. Environ. Poll. 157:2903-2927. http:// dx.doi.org/10.1016/j.envpol.2009.05.015

McCOY, K.A., Bortnick, L. J., CAMPBELL, C.M., HAMLIN, H.J., Jr. GUILLETTE, L.J. \& St. MARRY C.M. 2008. Agriculture Alters Gonadal Form and Function in the Toad Bufo marinus. Environ. Health. Perspect. 116(11): 1526-1532. http://dx.doi. org/10.1289/ehp.11536

MEENAKUMARI, D. 2007. Nitrate tolerance among anuran amphibians of central Western Ghats, Ph.D.Thesis, Kuvempu University. $171 \mathrm{p}$.

METEYER, C.U. 1997. Diagnostic findings associated with malformed frogs from Vermont. Final report USGS Science for changing world. 1-72.

METEYER, C.U. 2000. Field guide to malformation of frogs and toads with radiographic interpretations. Biological Science Report USGS/BRD/BSR-2000-0005.

NATARAJ, M.B. \& KRISHNAMURTHY, S.V. 2012. Effect of combinations of malathion and cypermetrin on survivability and time of metamorphosis of tadpoles of Indian cricket frog (Fejervarya limnocharis ). J. Environ. Sci. Health Part B. 47:6773. http://dx.doi.org/10.1080/03601234.2012.611428

OUELLET, M., BONIN, J., RODRIGUE, J., DESGRANGES, J.L. \& LAIR, S. 1997. Hindlimb deformities (ectromelia, ectrodactyly) in freeliving anurans from agricultural habitats. J. Wildl. Dis. 
33:95-104.

PALMER, B.D., HUTH, L.K., PIETO, D.L. \& SELCER, K.W. 1998. Vitellogenin as a biomarker for xenobiotic estrogens in an amphibian model system. Environ. Toxicol. Chem. 17:30-36. http://dx.doi.org/10.1002/etc.5620170105

PATEL, A.M., PRAVEEN KULKARNI, A., GIRISH, K.G., GURUSHANKARA H.P. \& KRISHNMAURTHY, S. V. 2008. Fejervarya limnocharis: Morphology. Herpetol. Review. 31(9): 77.

PAUNESCU, A. \& PONEPAL, C.M. 2011. Effect of roundup ${ }^{\circledR}$ herbicide on physiological indices in marsh frog Pelophylax ridibundus. Scientific Papers UASVM Bucharest, Series A. 54:269-274.

PEAKALL, D.B. 1976. Effects of toxaphene on hepatic enzyme induction and circulating steroid levels in the rat. Environ. Health. Perspect. 13:117-120.

PIHA, H., PEKKONEN, M. \& MERILA, J. 2006. Morphological abnormalities in amphibians in agricultural habitats. A case study of the common frog Rana temporaria. Copeia, 2006: 810-817.

RELYEA, R.A. 2009. A cocktail of contaminants: how mixtures of pesticides at low concentrations affect aquatic communities. Oecologia, 159:363-376. http://dx.doi.org/10.1007/s00442-0081213-9

REEVES, M.K., JENSEN, P., DOLPH, P.C., HOLYOAK, M. \& TRUST, K. 2010. Multiple stressors and the cause of amphibian abnormalities. Ecol. Monogr. 80: 423-440. http://dx.doi.org/ ORG/10.1890/09-0879

ROJAS-GARCIA, A.E., MEDINA-DÍAZ, I.M., ROBLEDOMARENCO, M.L., BARRÓN-VIVANCO, B.S. \& PÉREZ-
HERRERA, N. 2011. Pesticide biomarkers, pesticides in the modern world - pests control and pesticides exposure and toxicity assessment. 1-31p.

SCHULTE-HOSTEDDE, A.I, ZINNER, B., MILLAR, J.S. \& HICKLING, G.J. 2005. Restitution of mass - size residuals: validating body condition indices. Ecology, 86:155-163. http:// dx.doi.org/10.1890/04-0232

SMITH, G.R., KRISHNAMURTHY, S.V., BURGER, A.C. \& MILLS, L.B. 2011. Differential effects of malathion and nitrates exposure on American toad and wood frog tadpoles. Arch. Environ. Contam. Toxicol. 60:327-335. http://dx.doi. org/10.1007/s00244-010-9559-5

THAMMACHOTI, P., KHONSUE, W., KITANA, J., VARANUSUPAKUL, P. \& KITANA, N. 2012. Morphometric and gravimetric parameters of the rice frog Fejervarya limnocharis living in areas with different agricultural activity. J. Environ. Prot. 3:1403-408. http://dx.doi.org/10.4236/ jep.2012.310159

TONGO, I., EZEMONYE, L. \& OCHEI, U. 2012. Diazinon mediated biochemical changes in the African toad (Bufo regularis). J. Xenobiot. 2:18-23.

VASUDEV, V., KRISHNAMURTHY, S.V.\& GURUSHANKARA, H.P. 2007. Organophosphate pesticides- a major threat to anuran populations in an agroecosystem of Western Ghats, India. Froglog, 83:8-9.

WIDDER, P.D. \& BIDWELL, J.R. 2006. Cholinesterase activity and behavior in chlorpyrifos- exposed Rana sphenocephala tadpoles. Environ. Toxicol. Chem. 25:2446-2454. http://dx.doi. org/10.189705-522R.1. 